\title{
Interannual variability in chitobiase-based production rates of the crustacean zooplankton community in the Strait of Georgia
}

\author{
Akash R. Sastri ${ }^{1,3, *}$, John F. Dower ${ }^{1,2}$ \\ ${ }^{1}$ Department of Biology, University of Victoria, PO Box 3020, Station CSC, Victoria, British Columbia V8W 3N5, Canada \\ ${ }^{2}$ School of Earth and Ocean Sciences, University of Victoria, PO Box 3055 STN CSC Victoria, British Columbia V8W 3P6, Canada \\ ${ }^{3}$ Present address: Institute of Oceanography, National Taiwan University, No. 1, Sec. 4, Roosevelt Road, Taipei 10617 , Taiwan, ROC
}

\begin{abstract}
The temporal patterns of biomass development and biomass production rate (BP) of the crustacean zooplankton community in the Strait of Georgia, British Columbia, Canada, were tracked during the spring blooms of 2004 and 2005. BP was estimated directly using a method based on the turnover rate of the crustacean moulting enzyme, chitobiase. The relationship between individual chitobiase activity and body weight was found to be consistent for copepods, decapod larvae and mysids. The native activity of chitobiase in the water column was also found to vary significantly with the biomass derived from traditional plankton net tows. In 2004, chitobiase-based estimates of BP generally varied with temperature. The peak BP estimated in the spring of 2004 was $6.10 \mathrm{mg} \mathrm{C} \mathrm{m}^{-3}$ $\mathrm{d}^{-1}$, corresponding to biomass-dominance of the crustacean zooplankton community by the calanoid copepod Neocalanus plumchrus. In 2005, however, BP was unrelated to temperature and relatively low $\left(<2 \mathrm{mg} \mathrm{C} \mathrm{m}^{-3} \mathrm{~d}^{-1}\right)$ during the peak and early decline of the spring phytoplankton bloom. During the spring of 2005, the developing $N$. plumchrus population collapsed and has yet to recover.
\end{abstract}

KEY WORDS: Neocalanus $\cdot$ Calanus $\cdot$ Secondary production $\cdot$ Growth rate $\cdot$ Carbon flux $\cdot$ Copepod Mesozooplankton $\cdot$ British Columbia

Resale or republication not permitted without written consent of the publisher

\section{INTRODUCTION}

Crustacean zooplankton are the dominant intermediary between primary producers and ecologically and economically important higher trophic levels. Estimating the transfer efficiency of planktonic systems therefore requires measurements of both primary and secondary production rates. Although direct estimates of community-level primary production have long been available using routine methods (e.g. ${ }^{14} \mathrm{C}$ method; Steeman-Nielsen 1952), the few direct estimates of secondary production that exist have been limited to productive coastal systems and usually to only a few species (i.e. as opposed to the entire zooplankton community). This discrepancy can be attributed largely to the logistical difficulties associated with measuring the component parts of a secondary production estimate: growth rate and community biomass (Huntley \& Lopez 1992, Runge \& Roff 2000).
Oosterhuis et al. (2000) proposed a novel solution to this problem based on measuring the rate of production of the crustacean moulting enzyme, chitobiase. Chitobiase is one of 2 chitinolytic enzymes secreted by the arthropod epidermis into the apolytic space created when the old exoskeleton separates from the new exoskeleton. Chitobiase hydrolyses the dimeric Nacetyl-glucosamine (NAG) produced by the chitinasecatalyzed hydrolysis of polymeric NAG (chitin; Roff et al. 1994). Vrba \& Machacek (1994) first demonstrated that, following ecdysis, chitobiase is liberated into the surrounding water and its activity varies with individual body size. Oosterhuis et al. (2000) demonstrated that the chitobiase activity (CBA) liberated by moulting Temora longicornis copepodites varied directly with body size and the increment of growth. Using this relationship and measures of the rate of CBA decay, they directly estimated the biomass production rate (BP) of a synchronously developing culture without 
requiring estimates of biomass or growth rate. Recently, Sastri \& Dower (2006) reported a common relationship between CBA and body size for 4 marine copepod species and developed a simple protocol for routinely measuring chitobiase. The advantage of the method is that BP rates can be estimated directly and rapidly at sea.

Here we present a series of CBA-based production estimates from the Strait of Georgia (SoG), British Columbia, Canada, during 2004 and 2005. The SoG is a highly productive, semi-enclosed, estuarine system and an important feeding ground for several species of juvenile salmon and other economically important fish species (Harrison et al. 1983). The plankton ecology of the SoG has been reviewed by Harrison et al. (1983) and R. Pawlowicz et al. (unpubl.). Historically, mesozooplankton biomass in the SoG has been dominated by the large calanoid copepod Neocalanus plumchrus in the spring and by the euphausiid Euphausia pacifica during late spring and summer (Harrison et al. 1983). However, in 2005 the N. plumchrus population in the SoG collapsed and has yet to recover (J. F. Dower unpubl. data), and Metridia pacifica has emerged as the biomass-dominant copepod R. Pawlowicz et al. (unpubl.).

The present study was carried out in the SoG during the spring and early summer of 2004 and 2005, the objective being to investigate the utility and sensitivity of the chitobiase-method for directly estimating BP. Here, we consider whether the method can be extended to directly estimate production rates for the entire crustacean zooplankton community.

\section{MATERIALS AND METHODS}

Physical, chemical, and biological data. Basic hydrographic data (temperature, salinity, oxygen, chlorophyll and dissolved nutrients) and phytoplankton taxonomic data were provided by the Strait of Georgia Ecosystem Monitoring (STRATOGEM) project (www.stratogem.ubc.ca). A detailed account of the STRATOGEM sampling program is provided by Pawlowicz et al. (2007).

Zooplankton sampling, identification and enumeration. Sampling was carried out during the spring phytoplankton blooms and early summers of 2004 and 2005 at STRATOGEM Stn S4-1 $\left(49^{\circ} 15^{\prime} \mathrm{N}, 123^{\circ} 45^{\prime} \mathrm{W}\right)$ in the $400 \mathrm{~m}$ deep central basin of the SoG. Mesozooplankton were collected using a Scientific Committee on Oceanic Research (SCOR) type net (57 cm diameter mouth, $236 \mu \mathrm{m}$ mesh) equipped with a TSK flow meter and towed vertically from $100 \mathrm{~m}$ to the surface at $1 \mathrm{~m}$ $\mathrm{s}^{-1}$. Upon retrieval, the contents of the net were preserved in $10 \%$ buffered formalin. Back in the lab, sam- ples were split up to 5 times (i.e. 1/32) using a Folsom splitter. All crustacean zooplankton were identified to stage. Body lengths (prosome length for copepods) were measured at $25 \times$ magnification using a dissecting microscope equipped with an ocular micrometer. Abundances were converted to dry weight equivalents $\left(\mathrm{mg} \mathrm{m}^{-3}\right)$ using species-specific length- weight relationships obtained from the marine zooplankton database maintained by the Institute of Ocean Sciences, Sidney, British Columbia, Canada. A dry weight to carbon conversion factor of 0.45 was employed for all taxa (Paffenhöfer \& Harris 1976).

Chitobiase assay. All references to CBA in the present study refer to the activity of the crustacean moulting enzyme in $<0.2 \mu \mathrm{m}$ filtered seawater. A full description of the CBA assay is presented by Sastri \& Dower (2006). Briefly, reactions were initiated with the addition of the substrate 4-methylumbelliferyl- $\beta$-Dglucosaminide (0.1 mmol MBF-NAG; Sigma) to $0.2 \mu \mathrm{m}$ filtered seawater. The reaction was allowed to proceed for a defined period of time at $25^{\circ} \mathrm{C}$ (see below) and terminated by the addition of a $2 \mathrm{~N} \mathrm{NaOH}$ and $0.4 \mathrm{M}$ EDTA solution. Activity (nmol MBF liberated $\mathrm{l}^{-1} \mathrm{~h}^{-1}$ ) was estimated as the rate at which fluorescence of the liberated MBF moiety increased. Fluorescence was measured using a Turner Designs TD-700 fluorometer equipped with a long wavelength bulb, 300 to $400 \mathrm{~nm}$ excitation and 410 to $600 \mathrm{~nm}$ emission lenses. The reaction solution was buffered to pH 6.0 (Knotz et al. 2006, Sastri \& Dower 2006) using a 0.15 M citratephosphate buffer (McIlvaine 1921). Raw fluorescence was converted to nmol MBF by calibrating fluorescence against known concentrations of 4-methylumbelliferone (stock dissolved in cellosolve; Sigma).

CBA-biomass relationships. Chitobiase-based estimates of BP assume that the relationship between individual body size and CBA can be generalized to all members of the crustacean zooplankton community. This assumption was tested by comparing the CBA liberated by individual zoeal stages of the brown box crab Lopholithodes foraminatus and the mysid Neomysis sp. to that from the 4 copepod species (Calanus pacificus, Metridia pacifica, Pseudocalanus spp. and Tigriopus californicus) reported by Sastri \& Dower (2006).

Crab larvae were maintained in culture at the University of Victoria at 12 and $16^{\circ} \mathrm{C}$ and fed live Artemia salina, ad libitum (see Duguid \& Page in press for culture conditions and species description). Mysids were gently collected with a dip-net at low tide just off of the beach at Cadboro Bay, Victoria, British Columbia. For mysids, all moulting incubations were conducted within $4 \mathrm{~h}$ of collection. Crab larvae and mysids were carefully rinsed in sterilized seawater (previously heated to $75^{\circ} \mathrm{C}$ and $0.2 \mu \mathrm{m}$ filtered) and incubated in 10 to $50 \mathrm{ml}$ volumes, depending on individual size. Ani- 
mals were incubated in glass tubes or beakers at the temperature of collection or culture $\left(8\right.$ to $\left.16^{\circ} \mathrm{C}\right)$ for up to $12 \mathrm{~h}$. After the incubation period, incubations were inspected visually for the presence of exuviae. When an exuvium was observed, a 0.1 to $2.0 \mathrm{ml}$ subsample of seawater was withdrawn and used for CBA assays. Reaction times varied between 10 and 30 min and corresponded to the relative size of incubated individuals. Animals were passed quickly through distilled water, placed in pre-weighed aluminium tins and dried at $60^{\circ} \mathrm{C}$ for $24 \mathrm{~h}$. Dried animals were left at room temperature for an additional $48 \mathrm{~h}$ before weighing. After accounting for CBA-assay duration, incubation and subsample volumes, $\log _{\mathrm{e}}$-transformed individual CBA (nmol MBF $\mathrm{l}^{-1} \mathrm{~h}^{-1}$ ) was regressed against $\log _{\mathrm{e}}$ transformed dry weight. The resulting regression equation was then used to predict the individual CBA liberated by all crustaceans enumerated in each net cast. The total predicted CBA ( $\left.\mathrm{CBA}_{\text {sample }}\right)$ was calculated as:

$$
\mathrm{CBA}_{\text {sample }}=\Sigma\left(\mathrm{N}_{i} \times \mathrm{CBA}_{i}\right)
$$

where $\mathrm{N}_{i}$ represents the abundance $\left(\mathrm{l}^{-1}\right)$ of individuals in size class $i$ and $\mathrm{CBA}_{i}$ represents the predicted CBA liberated by an individual in the same size class. Estimates of $\mathrm{CBA}_{\text {sample }}$ from traditional plankton net tows (hereafter net-based estimates) were regressed against the native activity of chitobiase $\left(\mathrm{CBA}_{\text {nat }}\right)$ in the water column to assess the validity of scaling an individual-based relationship up to a community-level estimate. $\mathrm{CBA}_{\text {sample }}$ was also estimated without adult copepods and pre-overwintering (CV Neocalanus plumchrus, Calanus marshallae and Calanus pacificus) stages, a quantity which we denote as $\mathrm{CBA}_{\text {sample }}{ }^{*}$.

Chitobiase decay rate estimates. Chitobiase-based BP estimates are based on the rate at which crustacean zooplankton produce CBA via moulting in the water column. Like all enzymes, chitobiase is a protein, and is therefore susceptible to microbial proteases. We assume that a steady-state exists for zooplankton communities during the $12 \mathrm{~h}$ incubation period. $\mathrm{CBA}_{\text {nat }}$ is also assumed to be constant over the incubation period because its rate of production by moulting animals is balanced by its rate of decay in the water column. Therefore, the rate of CBA decay in seawater free of crustaceans is assumed to be equivalent to its rate of production. CBA decay rates were estimated from $54 \mu \mathrm{m}$ screened seawater samples $(\sim 1.0 \mathrm{l})$ collected from 5, 10, 30 and $50 \mathrm{~m}$. Ten $\mathrm{ml}$ subsamples were immediately $0.2 \mu \mathrm{m}$ filtered to estimate the native in situ chitobiase activity.

Following processing of seawater subsamples for $\mathrm{CBA}_{\text {nat }}$ assays, seawater samples from each depth were amended with a copepod homogenate 1 : 1000 $\mathrm{v} / \mathrm{v})$. The homogenate was used because the assay described above is not sensitive enough to discriminate the decay of $\mathrm{CBA}_{\text {nat }}$ from background noise. The homogenate consisted of 20 to 30 medium-sized copepodites ( 1.0 to $2.0 \mathrm{~mm}$ prosome length) homogenized in $4 \mathrm{ml}$ of seawater using a hand-held tissue grinder. The crude homogenate was passed through a $0.2 \mu \mathrm{m}$ filter before being used to spike the seawater samples. Seawater samples were then serially subsampled every 1.5 to $3 \mathrm{~h}$ for the next $12 \mathrm{~h}$. At each interval, the subsamples were passed through a $0.2 \mu \mathrm{m}$ filter and maintained in disposable glass test tubes at $4^{\circ} \mathrm{C}$ until assayed (within $12 \mathrm{~h}$ of the seawater incubation). The use of glass tubes is recommended as we have recently found that polycarbonate tends to bind the enzyme in an irregular fashion. All seawater samples were maintained at sea surface temperature (range $=6.5$ to $16.5^{\circ} \mathrm{C}$ depending on sampling date) during the $12 \mathrm{~h}$ incubation.

The depth-specific CBA decay rate $\left(\mathrm{h}^{-1}\right)$ was calculated as the slope $(k)$ of the natural logarithm of CBA in amended samples versus time. During the course of the present study, differences between incubation temperature (sea surface temperature) and the temperature at each sampled depth (i.e. 5, 10, 30 and $50 \mathrm{~m}$ ) varied by up to $1.75^{\circ} \mathrm{C}$ during spring, and by as much as $4.8^{\circ} \mathrm{C}$ in summer and autumn. A $Q_{10}$ of 3.15 was used to correct the measured slopes and thus estimate $\triangle \mathrm{CBA}$ at the in situ depth-specific temperature. The $Q_{10}$ was calculated as $\mathrm{e}^{(10 \times b)}$, where $b$ equals the slope of the natural logarithm of 158 CBA production rate $(-k)$ estimates against incubation temperature. Estimates of $-k$ used in this analysis represent all depths and dates used in the present study as well as estimates made at 6 stations off the west coast of Vancouver Island and 6 stations in the open subarctic Pacific sampled during both the spring and summer of 2005 and late winter of 2008 .

Calculation of biomass production rates. In general, this approach relates the production of CBA in the water column (by moulting animals) to the rate at which the standing biomass of developing animals is increasing. Previous studies (Oosterhuis et al. 2000, Sastri \& Roff 2000, Sastri \& Dower 2006) have demonstrated that CBA varies with individual size and growth increment. Thus, we estimate biomass production as the time (rate of CBA production) it would take $\mathrm{CBA}_{\text {nat }}$ (the sum of all individual growth) to be produced in the water column.

The time $\left(T_{\mathrm{CBA}}\right)$ taken for moulting crustaceans to produce CBA equivalent to the activity measured in the water column $\left(\mathrm{CBA}_{\text {nat }}\right)$ was estimated as the reciprocal of the negative slope $(1 /-k)$. Note that $T_{\mathrm{CBA}}$ is equivalent to the estimate of average community-level stage duration calculated by Sastri \& Dower (2006) as $\mathrm{CBA}_{\text {nat }} / \triangle \mathrm{CBA}$. As stated above, we assume that: (1) the 
crustacean zooplankton community is in steady state for the $12 \mathrm{~h}$ incubation period and (2) the rate of production of chitobiase is balanced by its rate of decay. The relationship between CBA and the growth increment of copepods $\left(\log \left(g_{\text {inc }}\right)=0.864 \log \left(\mathrm{CBA}_{i}\right)-1.78\right.$; Sastri \& Dower 2006) was applied to the depthweighted average $\mathrm{CBA}_{\text {nat }}$ to estimate the absolute amount of biomass produced $(\Delta B)$. Thus the daily biomass production rate $(\mathrm{BP})$ is calculated as:

$$
\mathrm{BP}=\Delta B / T_{\mathrm{CBA}}
$$

Evaluation of daily production to biomass ratios. In an effort to compare the relative correspondence between CBA-based and conventional BP estimates we calculated and compared estimates of daily pro- duction to biomass ratios (P:B). Chitobiase-based $\mathrm{P}: \mathrm{B}$ was estimated as the ratio of $\mathrm{BP}$ estimated directly from CBA production rate estimates and the total crustacean zooplankton biomass estimated from $\mathrm{CBA}_{\text {nat }}$ using the individual CBA-body weight (BW) relationship described below. For comparison, we also estimated P:B by applying individual weight-specific growth rates relationships for: (1) broadcast spawning juvenile copepods (Hirst \& Bunker 2003: $\log _{10} g=$ $\left.-0.0143 T-0.363\left[\log _{10} \mathrm{BW}\right]+0.135\left[\log _{10} \mathrm{chl} a\right]-0.392\right)$;

(2) sac-spawning juvenile copepods (Hirst \& Bunker 2003: $\left.\log _{10} g=0.0333 T-0.163\left[\log _{10} \mathrm{BW}\right]-1.528\right)$; and (3) non-copepod crustaceans (Hirst et al. 2003: $\log _{10} g=$ $\left.0.0263 T-0.327\left[\log _{10} \mathrm{BW}\right]-0.919\right)$ to individual biomass and abundance estimates from our net casts.
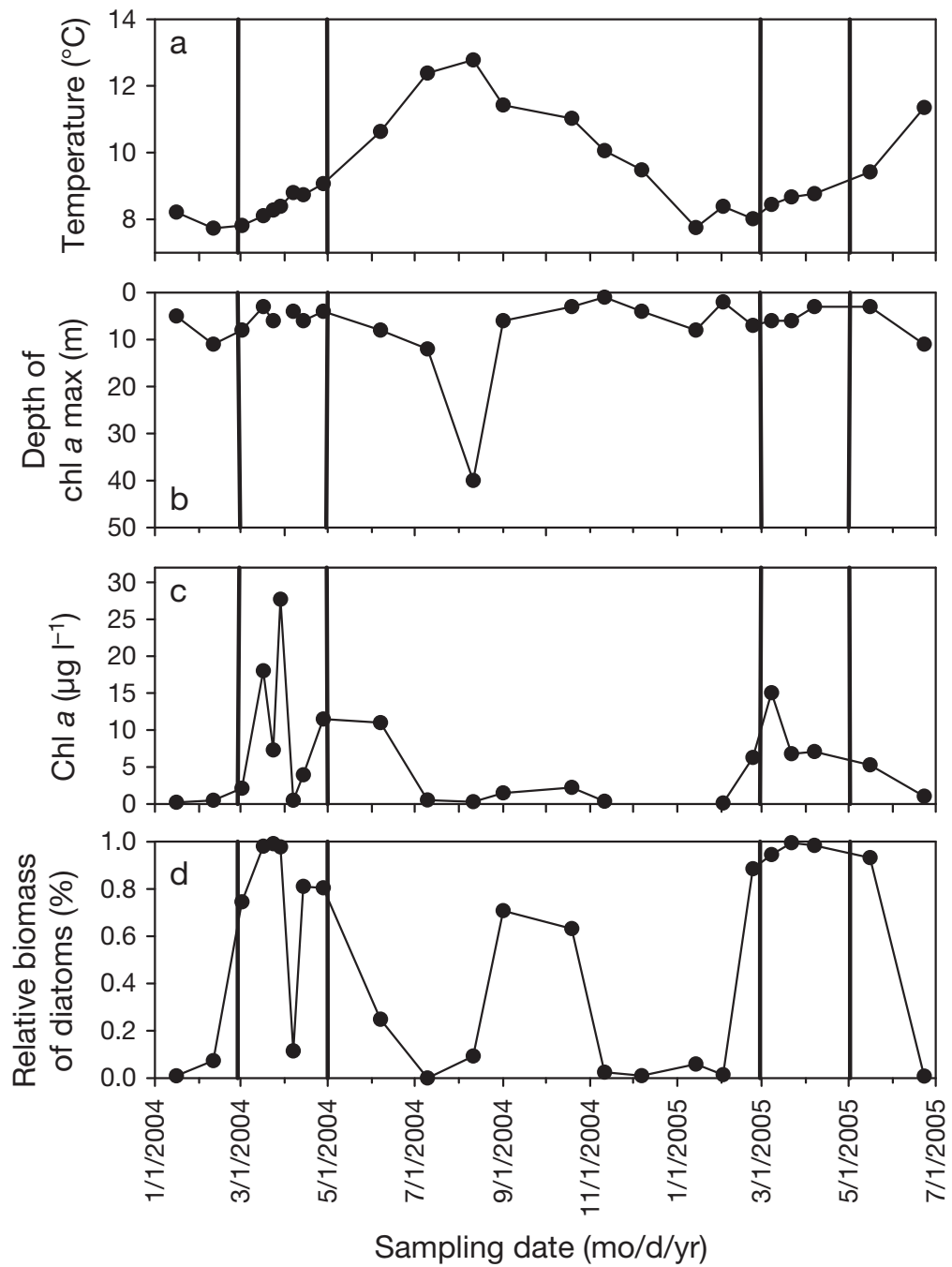

Fig. 1. Time series (16 January 2004 to 23 June 2005) of water column properties at STRATOGEM Stn S4-1. (a) Depth-averaged (0 to $50 \mathrm{~m}$ ) temperature $\left({ }^{\circ} \mathrm{C}\right)_{i}(\mathrm{~b})$ average depth $(\mathrm{m})$ of the chlorophyll a ( $\left.\mathrm{chl} \mathrm{a}\right)$ maximum $_{i}(\mathrm{c})$ depthintegrated (upper $10 \mathrm{~m}$ ) average chl a concentration $\left(\mu \mathrm{g} \mathrm{l}^{-1}\right)$ in the $>2.0 \mu \mathrm{m}$ size fraction; (d) proportion of phytoplankton community composition at $5 \mathrm{~m}$ accounted for by diatoms. Vertical lines denote spring periods (1 March to 1 May 2004 and 2005)

\section{RESULTS}

\section{Water column properties}

The average temperature ( 0 to $50 \mathrm{~m})$ at Stn S4-1 varied seasonally. The highest average temperature was $12.8^{\circ} \mathrm{C}$ on 11 August 2004 (Fig. 1). The average temperature over the entire study period was $9.3^{\circ} \mathrm{C}( \pm 0.3)$ and $8.5^{\circ} \mathrm{C}( \pm 0.12)$ during both spring blooms. The degree of water column stratification $\left(\Delta \sigma_{t}\right)$ was estimated as the difference between the average $\sigma_{\mathrm{t}}$ for the upper $10 \mathrm{~m}$ and the $\sigma_{\mathrm{t}}$ at $50 \mathrm{~m}$. The period of greatest stratification occurred between June and September 2004. The strong stratification during this period (Fig. 2a) was accompanied by high surface water temperatures and an almost complete exhaustion of nitrate at $5 \mathrm{~m}$ (Fig. 2b). Phosphate and silicate concentrations (Fig. 2c,d) were also depleted during the summer relative to winter levels. The minimum silicate concentrations at $5 \mathrm{~m}$ during the study period were 1.72 and $4.98 \mu m o l ~^{-1}$ on 8 and 22 March 2005, respectively. The minimum phosphate concentration $\left(0.24 \mu \mathrm{mol} \mathrm{l^{-1 }}\right)$ was also observed on 8 March 2005. Minima of both silicate and phosphate coincided with the peak diatom biomass (Fig.1d; relative to ciliates, dinoflagellates and flagellates).

The degree of stratification during March 2004 was relatively low. Stratification increased in April 2004 but was also characterized by intermittent mixing. In contrast, in 2005 water column stratifica- 

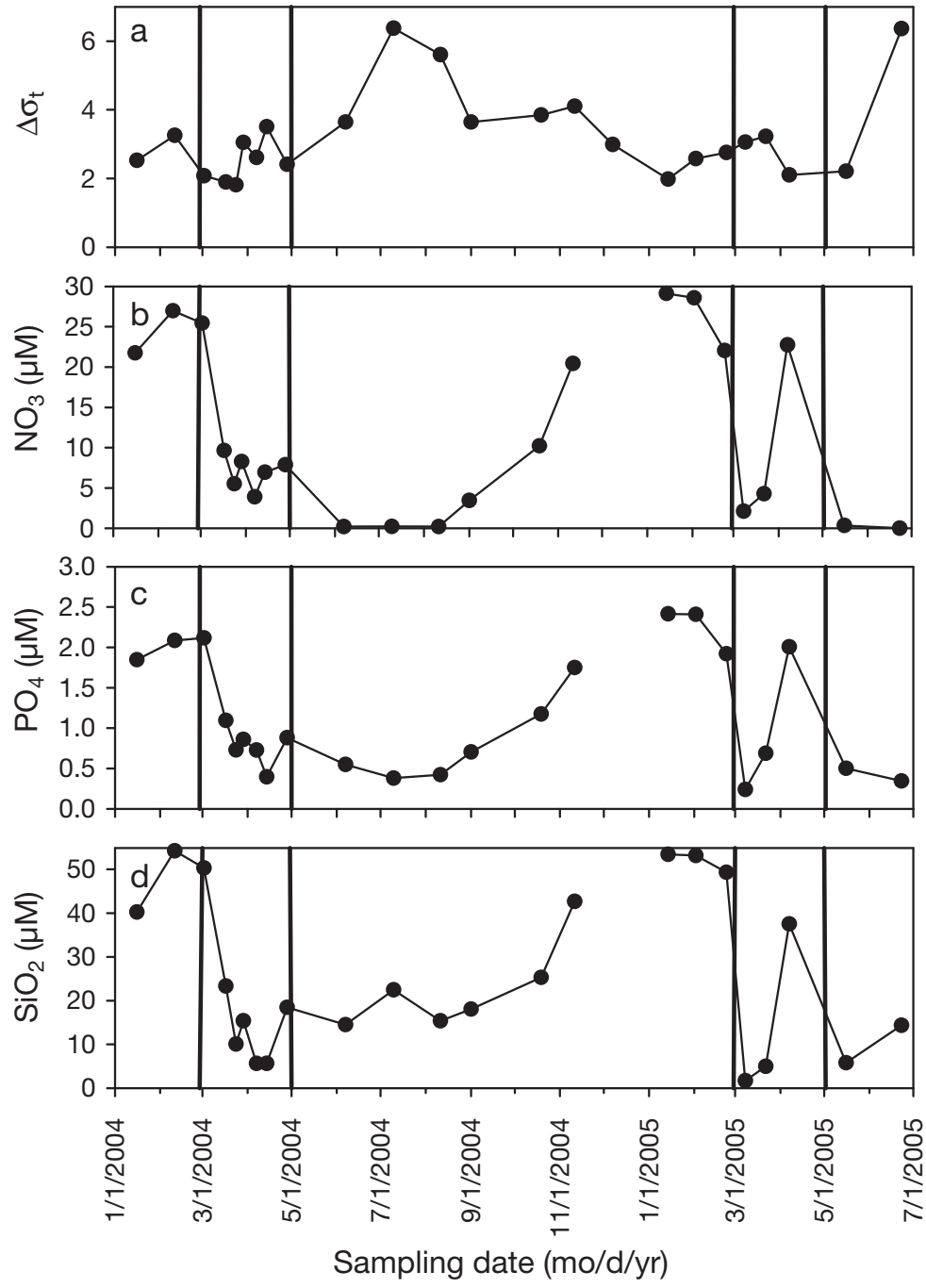

Fig. 2. Time series (16 January 2004 to 23 June 2005) of physico-chemical properties at STRATOGEM Stn S4-1. (a) Stratification parameter $\left(\Delta \sigma_{t}\right)$ estimated as the difference between the mean $\sigma_{t}$ for the upper $10 \mathrm{~m}$ and the maximum $\sigma_{\mathrm{t}}$ for the upper $50 \mathrm{~m}$; (b) depth-integrated average $\mathrm{NO}_{3}$ concentration $(\mu \mathrm{M})$ at $5 \mathrm{~m}_{i}(\mathrm{c})$ depth-integrated average $\mathrm{PO}_{4}$ concentration $(\mu \mathrm{M})$ at $5 \mathrm{~m}_{i}(\mathrm{~d})$ depth-integrated average $\mathrm{SiO}_{2}$ concentration $(\mu \mathrm{M})$ at $5 \mathrm{~m}$. Vertical lines denote spring periods (1 March to 1 May 2004 and 2005)

tion appears to have been established by early February. Stratification continued to increase until at least 22 March 2005, after which mixing of the nutrientdepleted surface mixed layer with deeper nutrient rich waters occurred. The average depth of maximum chlorophyll fluorescence during the study was $7.3 \mathrm{~m}$ (Fig. 1b; SE = 1.6) and was always between $10 \mathrm{~m}$ and the surface during both spring bloom periods. The peak chlorophyll a concentration (0 to $10 \mathrm{~m}$ depthaveraged) in the $>2.0 \mu \mathrm{m}$ size fraction during each spring phytoplankton bloom was 28.37 and $14.36 \mathrm{Mg} \mathrm{l}^{-1}$ on 29 March 2004 and 8 March 2005, respectively (Fig. 1C).

\section{Biomass composition of the crustacean zooplankton community}

The time series of crustacean zooplankton community biomass is presented in Fig. 3a. Biomass peaked on 29 March 2004 (25.17 mg dry weight [DW] $\mathrm{m}^{-3}$ ) and 8 March 2005 (26.58 $\mathrm{mg} \mathrm{DW} \mathrm{m}^{-3}$ ). The observed biomass minima, 3.42 and $2.44 \mathrm{mg} \mathrm{DW} \mathrm{m}{ }^{-3}$, occurred on 16 January 2004 and 14 January 2005, respectively. In both years, copepods dominated the peak and minimum biomass periods. Euphausia pacifica dominated the biomass of noncopepod crustacean zooplankton (Fig. 3a). In 2004, E. pacifica biomass began to increase in late spring and peaked $(5.95 \mathrm{mg}$ DW $\mathrm{m}^{-3}$ ) in early June. In 2005, E. pacifica biomass peaked (3.34 mg $\mathrm{DW} \mathrm{m}^{-3}$ ) in midMay. The peak larval decapod biomass was 1.06 and $7.53 \mathrm{mg} \mathrm{DW} \mathrm{m}{ }^{-3}$ on 2 March 2004 and 8 March 2005, respectively. Aside from secondary peaks in early June 2004 and early April 2005, net-based decapod biomass never exceeded $1 \mathrm{mg} \mathrm{DW} \mathrm{m} \mathrm{m}^{-3}$. Amphipod biomass was greatest in late April and early of June 2004 and in June 2005. The 'other' category is composed of cladocerans, isopods, ostracods and barnacle larvae. Ostracod biomass was variable, but generally $<2 \mathrm{mg} \mathrm{DW} \mathrm{m}^{-3}$ with the exception of 23 June 2005 (4.05 mg DW $\left.\mathrm{m}^{-3}\right)$. Isopod biomass was always low $\left(<0.4 \mathrm{mg} \mathrm{DW} \mathrm{m}^{-3}\right)$ with no apparent temporal pattern. Cladocera (Evadne sp. and Podon sp.) were only present $(<0.1 \mathrm{mg}$ DW $\mathrm{m}^{-3}$ ) on 7 June 2004 and 16 May 2005. In 2004, the biomass of barnacle nauplii and cyprid stages was $<1 \mathrm{mg} \mathrm{DW} \mathrm{m}^{-3}$; however, in 2005, the combined biomass of these stages increased from 1.2 to $>5 \mathrm{mg} \mathrm{DW} \mathrm{m}^{-3}$ between late February and early May.

Copepod biomass was partitioned into moulting (i.e. nauplii and copepodites) and non-moulting (i.e. adults and pre-wintering CVs) fractions (Fig. 3a). The peak biomass of both groups (combined) was observed on 29 March (21.31 mg DW m${ }^{-3}$ ) and 8 March 2004 (15.68 $\mathrm{mg} \mathrm{DW} \mathrm{m}^{-3}$ ) and 23 June 2005 (16.34 mg DW $\mathrm{m}^{-3}$ ). The peak non-developing biomass was measured on 7 April 2004 (10.83 $\mathrm{mg} \mathrm{DW} \mathrm{m}^{-3}$ ) and 8 March 2005 (11.01 $\mathrm{mg} \mathrm{DW} \mathrm{m}^{-3}$ ). By subtraction, the developing biomass was greatest on 29 March 2004 (13.75 $\mathrm{mg} \mathrm{DW} \mathrm{m}^{-3}$ ) and 23 June 2005 (10.92 $\mathrm{mg} \mathrm{DW} \mathrm{m}^{-3}$ ). However, the developing copepod biomass during the spring of 2005

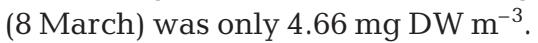




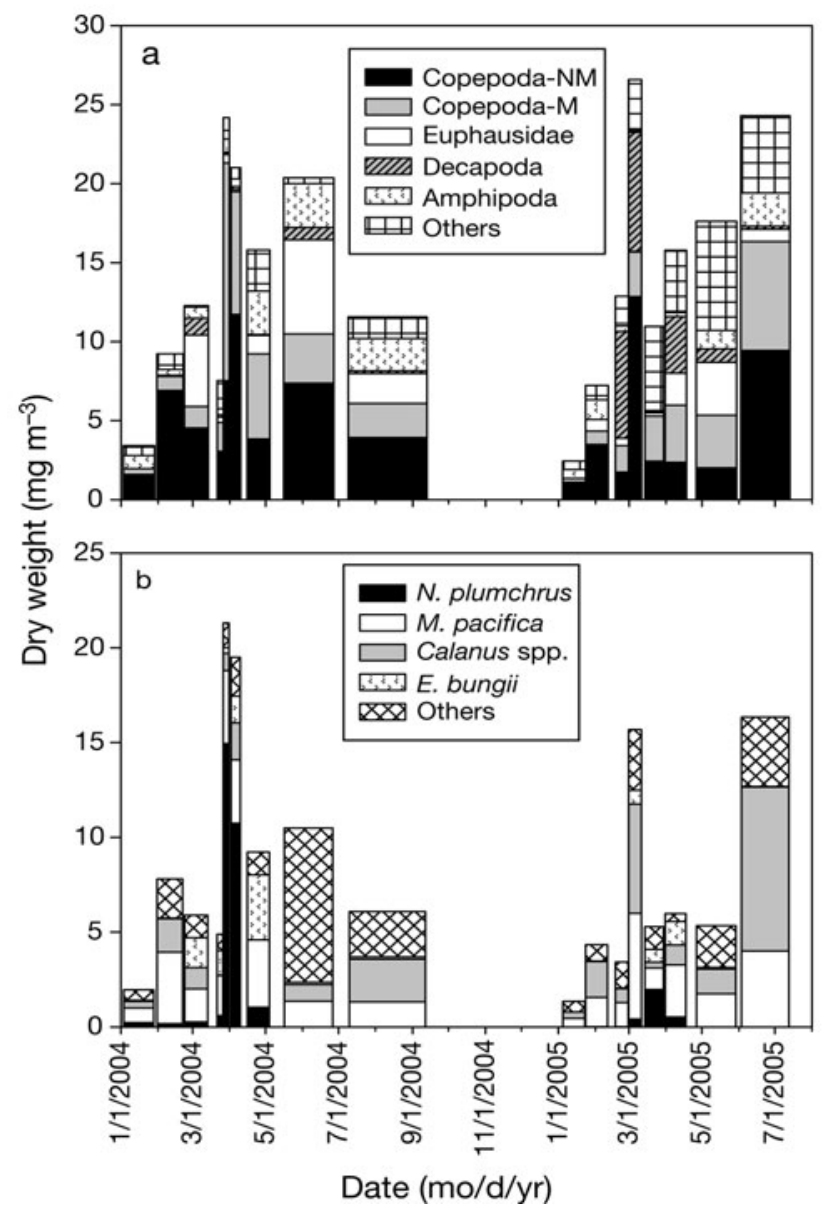

Fig. 3. (a) Composition of crustacean zooplankton biomass in the Strait of Georgia during 2004 and 2005 based on 0 to $100 \mathrm{~m}$ SCOR-net tows. Copepod community is partitioned into nonmoulting (NM; all adults and CV Calanus spp., and Neocalanus plumchrus) and moulting (M) biomass. 'Others' is composed of cladocerans, isopods, ostracods and barnacle larvae. (b) Netbased pattern of copepod community biomass in the Strait of Georgia during 2004 and 2005. Each vertical bar has been expanded to accommodate the time between sampling dates.

M. pacifica: Metridia pacifica; E. bungii: Euphausia bungii

When examined in more detail (Fig. 3b), we find that copepod biomass in 2004 was dominated by Neocalanus plumchrus (peak biomass $=14.95 \mathrm{mg} \mathrm{DW} \mathrm{m}^{-3}$ on 29 March). In 2005, biomass dominance was shared by Metridia pacifica, Calanus marshallae and C. paci-

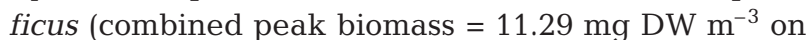
8 March). The peak biomass of $N$. plumchrus in surface waters during 2005 was $2.03 \mathrm{mg} \mathrm{DW} \mathrm{m}^{-3}$ on 22 March. The estimates in Fig. 3b also include the biomass of smaller but numerically abundant species from the 'other' category, including Acartia longiremis, Centropages abdominalis, Corycaeus anglicus, Euchaeta elongata, Microcalanus spp., Microsetella spp., Oncaea spp., Oithona spp., Paracalanus parvus, Pseudocalanus spp. and Scolecithricella minor.

\section{Chitobiase-biomass relationships}

The relationship between individual dry weight and CBA for copepods, decapod larvae and mysids was described as: $\log _{\mathrm{e}}(\mathrm{CBA})=1.55 \log _{\mathrm{e}}(\mathrm{DW})+5.60\left(\mathrm{r}^{2}=\right.$ $0.949, \mathrm{p}<0.001)$. The SE of the estimate was 0.703. A direct prediction of $\mathrm{CBA}_{i}$ using the relationship in Fig. 4a returns a geometric mean, potentially inflating estimates of prediction error (see Bird \& Prairie 1985). A relatively severe correction factor $(\mathrm{CF})$ of 1.28 was calculated as $\left.\mathrm{CF}=\exp \left(\mathrm{SE}^{2} / 2\right)\right)$ and applied to all predicted values below.

When expressed as CBA, the total biomass of the crustacean zooplankton community sampled in the 0 to $100 \mathrm{~m}$ net casts varied significantly with $\mathrm{CBA}_{\text {nat }}$ as $\mathrm{CBA}_{\text {nat }}=$
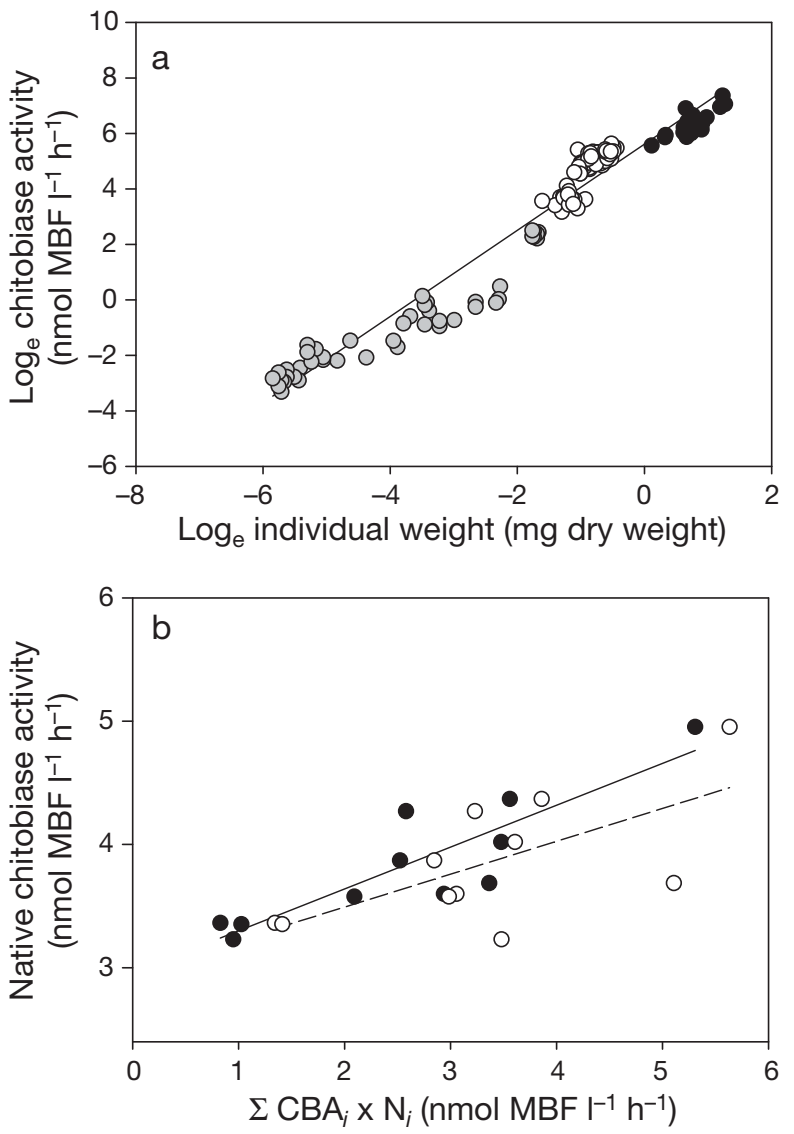

Fig. 4. (a) Regression of $\log _{\mathrm{e}}$ chitobiase activity $\left(\mathrm{CBA}_{i} \mathrm{nmol}\right.$ methylumbelliferyl [MBF] $\mathrm{l}^{-1} \mathrm{~h}^{-1}$ ) liberated by individual planktonic Crustacea versus $\log _{e}$ individual dry weight (mg). Marine copepods (Tigriopus californicus, Pseudocalanus sp., Metridia pacifica and Calanus pacificus) are represented by grey circles, white circles represent zoeal stages of Lopholithodes foraminatus and black circles represent Neomysis sp. (b) Regression of depth-averaged native $\mathrm{CBA}\left(\mathrm{CBA}_{\text {nat }}\right)$ versus net-based estimates of crustacean zooplankton biomass $\left(\sum \mathrm{N}_{i} \mathrm{CBA}_{i}\right)$. Crustacean biomass including non-moulting stages $\left(\mathrm{CBA}_{\text {sample }}\right)$ is represented by white circles; biomass with non-moulters removed $\left(\mathrm{CBA}_{\text {sample }}{ }^{*}\right)$ is represented by black circles. Note the value for 2 March 2004 was removed from regression analyses 
$0.27 \mathrm{CBA}_{\text {sample }}+2.96\left(\mathrm{r}^{2}=0.44, \mathrm{p}=0.026 ;\right.$ Fig. 4b). A stronger relationship emerged when $\mathrm{CBA}_{\text {nat }}$ values were regressed against developing copepod biomass: $\mathrm{CBA}_{\text {nat }}=$ $0.34 \mathrm{CBA}_{\text {sample }}{ }^{*}+2.961\left(\mathrm{r}^{2}=0.78, \mathrm{p}<0.001\right.$; Fig. 4b). A single outlier was identified with the studentized residual analysis as having a residual greater than 3 . The $\mathrm{CBA}_{\text {nat }}$ and corresponding $\mathrm{CBA}_{\text {sample }}$ and $\mathrm{CBA}_{\text {sample }}{ }^{*}$ estimates (1.16, 6.63 and 5.74, respectively) for 2 March 2004 were eliminated and not included in the regression analysis above. Note that in this case application of the $\mathrm{CF}$ reduced the value of the slope, but the intercept and correlation coefficient remain unchanged.

\section{Chitobiase decay and BP}

Variation of CBA decay rates in seawater incubations relative to incubation temperature is described as: $\log _{e}(-k)=0.115$ (incubation temperature) $-5.54\left(\mathrm{r}^{2}=\right.$ 0.317, $\mathrm{p}<0.001, \mathrm{n}=158$; Fig. 5), where the relative rate of production of CBA is expressed as $-k$. The in situ temperature dependence of chitobiase production rate is described by a $Q_{10}$ of 3.15 , calculated as $\mathrm{e}^{(10 \times 0.115)}$.

The maximum BP in 2004 was $9.97 \mathrm{mg} \mathrm{C} \mathrm{m}^{-3} \mathrm{~d}^{-1}$ on 11 August 2004 (Fig. 6a, Table 1). During spring 2004, the maximum BP rate observed was $6.10 \mathrm{mg} \mathrm{C} \mathrm{m}^{-3} \mathrm{~d}^{-1}$ on 7 April. In 2005, community BP was $<3.2 \mathrm{mg} \mathrm{C} \mathrm{m}^{-3}$ $\mathrm{d}^{-1}$ from 23 February through 22 March (Fig. 6b, Table 1). By early April, however, the rate had rebounded (9.91 $\mathrm{mg} \mathrm{C} \mathrm{m}^{-3} \mathrm{~d}^{-1}$ on 7 April) and generally remained at this level before declining to $2.97 \mathrm{mg}$ $\mathrm{C} \mathrm{m}^{-3} \mathrm{~d}^{-1}$ on 23 June. When all estimates were considered, there was a significant positive correlation between BP and temperature (Spearman's rank corre-

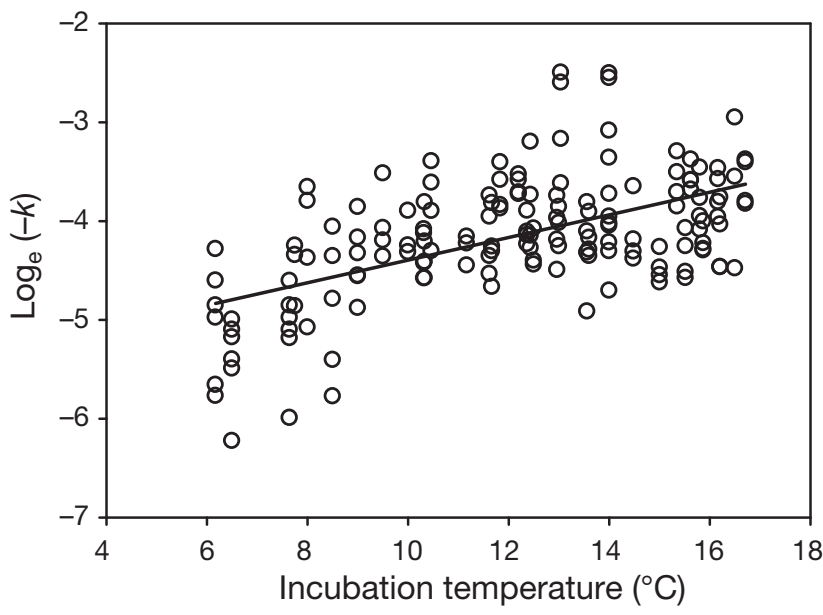

Fig. 5. Relationship between incubation temperature $\left({ }^{\circ} \mathrm{C}\right)$ and the natural logarithm of CBA production $(-k)$ in the water column. Points represent depth-specific decay rate $(k)$ estimates from the Straits of Georgia, the west coast of Vancouver Island and the open subarctic northeast Pacific made in 2004, 2005 and 2008

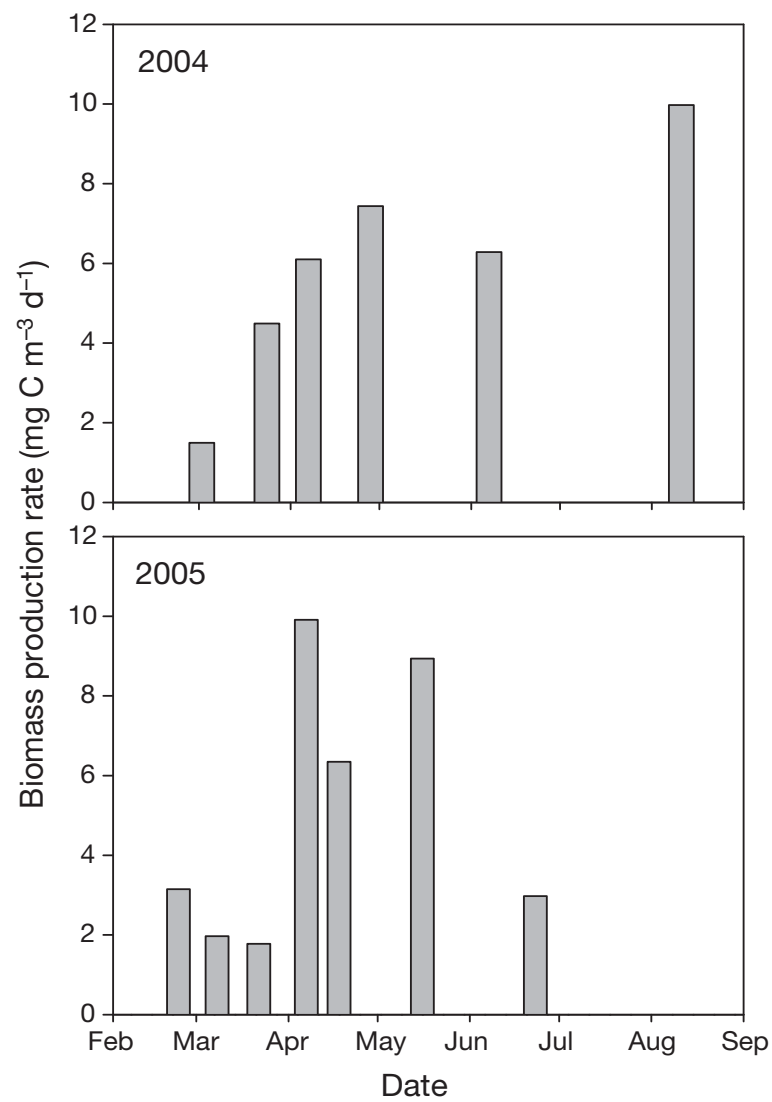

Fig. 6. Temporal pattern of chitobiase-based biomass production rates measured in the Strait of Georgia during the spring and summer in 2004 and 2005

lation, $\left.r_{S}=0.615, p=0.024\right)$. The strength of the correlation increased when BP estimates for just 2004 were considered $\left(r_{S}=0.943, p=0.017\right)$. In contrast, there was no significant correlation between $\mathrm{BP}$ and temperature in 2005. There were no relationships between BP and either net-based biomass or $>2 \mu \mathrm{m}$ chlorophyll a concentration, regardless of whether the years were considered separately or combined. It should be noted that Fig. 6b includes a single BP estimate for 17 April 2009 that is not otherwise evaluated in the present study. We were not able to include this estimate in our analyses because we did not collect a 0 to $100 \mathrm{~m}$ zooplankton sample nor were we able to estimate chlorophyll $a$.

\section{Daily P:B}

The relative turnover rate of developing biomass (P:B) estimated using CBA-derived parameters and a combination of literature-derived and net-based estimates are presented in Table 1. There was no statistically significant correlation between these 2 estimates. The mean CBA-based P:B was $0.2( \pm 0.098)$ and the mean literature-based P:B was $0.11( \pm 0.033)$. 
Table 1. Date-specific point measurements and estimates of developing biomass, average individual weight, temperature (0 to $50 \mathrm{~m}$ ), chitobiase activity (CBA)-based estimates of biomass production rate (BP) and composite BP estimates using weightspecific growth rates estimated from Hirst \& Bunker (2003) and Hirst et al. (2003). Total net-based biomass of crustacean zooplankton excludes the biomass of non-moulting animals. Numerically weighted mean-sized individual is estimated from developing biomass collected by nets. Daily production:biomass (P:B) estimates were calculated directly from CBA-based parameters, composite production rates and net biomass

\begin{tabular}{|lccccccc|}
\hline $\begin{array}{l}\text { Date } \\
(\mathrm{mo} / \mathrm{d} / \mathrm{yr})\end{array}$ & $\begin{array}{c}\text { Total biomass } \\
\left(\mathrm{mg} \mathrm{C} \mathrm{m}^{-2}\right)\end{array}$ & $\begin{array}{c}\text { Mean-sized } \\
\text { individual } \\
(\mu \mathrm{g} \mathrm{C})\end{array}$ & $\begin{array}{c}\text { Temperature } \\
\left({ }^{\circ} \mathrm{C}\right)\end{array}$ & $\begin{array}{c}\mathrm{CBA}-\mathrm{BP} \\
\left(\mathrm{mg} \mathrm{C} \mathrm{m}^{-2} \mathrm{~d}^{-1}\right)\end{array}$ & $\begin{array}{c}\text { Composite BP } \\
\left(\mathrm{mg} \mathrm{C} \mathrm{m}^{-2} \mathrm{~d}^{-1}\right)\end{array}$ & $\begin{array}{c}\text { Daily P:B } \\
(\mathrm{CBA})\end{array}$ & $\begin{array}{c}\text { Daily P:B } \\
(\mathrm{Composite})\end{array}$ \\
\hline 3/2/2004 & 348.06 & 29.31 & 7.81 & 74.80 & 21.58 & 0.12 & 0.06 \\
$3 / 24 / 2004$ & 201.26 & 12.26 & 8.27 & 224.54 & 32.05 & 0.18 & 0.16 \\
$4 / 7 / 2004$ & 418.08 & 8.16 & 8.80 & 305.13 & 72.77 & 0.25 & 0.17 \\
$4 / 28 / 2004$ & 538.20 & 23.30 & 9.06 & 371.86 & 68.98 & 0.25 & 0.13 \\
$6 / 7 / 2004$ & 585.22 & 9.67 & 10.63 & 314.17 & 72.88 & 0.23 & 0.12 \\
$8 / 11 / 2004$ & 344.24 & 11.19 & 12.77 & 498.78 & 26.46 & 0.33 & 0.08 \\
2/23/2005 & 501.43 & 22.06 & 8.01 & 157.48 & 39.65 & 0.11 & 0.08 \\
$3 / 8 / 2005$ & 617.76 & 21.94 & 8.44 & 98.48 & 57.19 & 0.07 & 0.09 \\
$3 / 22 / 2005$ & 383.67 & 14.40 & 8.66 & 88.93 & 47.33 & 0.07 & 0.12 \\
$4 / 7 / 2005$ & 603.95 & 25.81 & 8.76 & 495.56 & 62.82 & 0.30 & 0.10 \\
$5 / 16 / 2005$ & 702.43 & 22.83 & 9.42 & 446.75 & 70.68 & 0.34 & 0.10 \\
$6 / 23 / 2005$ & 668.33 & 29.31 & 11.02 & 148.78 & 79.46 & 0.11 & 0.12 \\
\hline
\end{tabular}

\section{DISCUSSION}

\section{Evaluation of chitobiase-based estimates of production}

A single community-based estimate of BP assumes a common relationship between body size and enzyme activity. That the 4 copepod species examined by Sastri \& Dower (2006) shared a common CBA-body size relationship is not surprising given their shared body morphology. However, the results in Fig. 4a suggest that a single CBA-body size relationship can be extended to mysids and larval decapods and, presumably, to other planktonic crustaceans. Further work will be required to confirm that this is indeed the case.

Significant positive relationships between total crustacean zooplankton biomass and $\mathrm{CBA}_{\text {nat }}$ were found when our 0 to $100 \mathrm{~m}$ net-based biomass estimates were expressed as $\Sigma\left(\mathrm{N}_{i} \mathrm{CBA}_{i}\right)$. This is significant, as it demonstrates that variation of $\mathrm{CBA}_{\text {nat }}$ is representative of variation in community-level biomass. Moreover, a stronger relationship emerged when the non-developing biomass was excluded $\left(\mathrm{r}^{2}\right.$ increased from 0.41 to $0.74)$. In laboratory cultures of Temora longicornis, $\mathrm{CBA}_{\text {nat }}$ varied closely with biomass during cohort development (Oosterhuis et al. 2000). In their Fig. 5, $\mathrm{CBA}_{\text {nat }}$ appears to decline as the average developmental stage and biomass includes a greater proportion of non-developing adults. Their laboratory study, together with the present field study, therefore suggests that variation of $\mathrm{CBA}_{\text {nat }}$ is best explained by the biomass of moulting animals. The strong correspondence between $\mathrm{CBA}_{\text {nat }}$ and biomass in $100 \mathrm{~m}$ net casts also suggests that: (1) the daytime depth of migration at our station is close to 100; and (2) our assumptions of steady state and a balance between production and decay were not violated.

Several factors may explain the absence of a 1:1 relationship between $\mathrm{CBA}_{\text {nat }}$ and $\mathrm{CBA}_{\text {sample }}{ }^{*}$ in the present study. First, it is possible that our $236 \mu \mathrm{m}$ mesh net did not adequately sample the entire crustacean zooplankton community. Second, plankton nets (in general) consistently underestimate biomass (Stehle et al. 2007), particularly for larger taxa such as euphausiids. Third, during periods of low food quality and/or quantity, juveniles present in the water column may not be developing and are therefore not contributing to the CBA pool (Crain \& Miller 2001, Campbell et al. 2001). A definitive field validation of the correspondence between $\mathrm{CBA}_{\text {nat }}$ and biomass will require an accurate estimate of the developing community biomass, which in turn will require the use of multiple sampling gears, ideally during periods of food-saturated development.

Estimating biomass production from $\mathrm{CBA}_{\text {nat }}$ and chitobiase decay rate estimates takes advantage of the relationship between individual growth increment and liberated CBA (Eq. 2). However, scaling individualbased estimates up to $\Delta B$ requires that the slope of the individual-based relationship be 1 . Thus, by predicting $\Delta B$ using the slope $(0.86)$ of the regression presented by Sastri \& Dower (2006), we have slightly underestimated $\Delta B$ and thus BP. A correction would require an accurate estimate of the absolute abundance of all actively developing individuals. However, since total crustacean zooplankton biomass varied significantly with $\mathrm{CBA}_{\text {nat, }}$ this suggests that the error is at least consistent across the time series and that our estimates are internally consistent. Oosterhuis et al. (2000) reported 
a relationship between growth increment and CBA for Temora longicornis copepodites that approached 1. The regression used here does not include mysids or decapod larvae, as we did not monitor their growth increments. For copepods, the growth increment was calculated using length-weight relationships which may result in an overestimate of growth increment relative to CBA. Ideally, future considerations of this relationship should directly measure the increment of growth relative to individual CBA.

The decay rate of $\mathrm{CBA}$ in the water column represents the turnover rate of $\mathrm{CBA}_{\text {nat }}$ produced by the developing crustacean zooplankton. Sastri \& Dower (2006) proposed that this rate is equivalent to the average moulting rate of the community. In terms of validation, Sastri \& Dower (2006) found good correspondence between moulting rates estimated using conventional incubations and the turnover rate of the enzyme $\left(T_{\mathrm{CBA}}\right)$ in the water column. Here we find that $T_{\mathrm{CBA}}$ generally varies with temperature-based expectations. As part of method development, we also estimated a $Q_{10}$ for CBA decay rate. This value was used to correct rates for differences between incubation temperature and depthspecific temperatures. Although estimated from in situ rates, the $Q_{10}$ for the present study corresponds well with a $Q_{10}$ of 3.22 for temperature-dependence of microbial protease activity (Hollibaugh \& Azam 1983) and $Q_{10}$ values for copepod development time (Huntley \& Lopez 1992, Kiørboe \& Sabatini 1995).

As noted previously, studies against which to compare our direct estimates of production for an entire crustacean zooplankton community are virtually nonexistent. Harrison et al. (1983) calculated a production value equivalent to $4.05 \mathrm{mg} \mathrm{C} \mathrm{m} \mathrm{m}^{-3} \mathrm{~d}^{-1}$ for the developing Neocalanus plumchrus population sampled in the SoG during the spring of 1967 (using growth and biomass data from Parsons et al. 1969). Parsons et al. (1969) estimated growth via changes in individual weight and stage distribution in the upper $20 \mathrm{~m}$. Peterson et al. (2002) did report production rates from a copepod community similar to that of the SoG, and directly estimated a combined (female and juvenile) production rate of $2.1 \mathrm{mg} \mathrm{C} \mathrm{m} \mathrm{C}^{-3} \mathrm{~d}^{-1}$ during summer upwelling off the Oregon coast. Their estimates of adult and somatic growth rate were not considered to be food-limited. By comparison, our BP estimates only consider juveniles. Typically, our estimates of community-level production rates in the SoG are up to about 5 times higher than those of Peterson et al. (2002). Recently, R. Pawlowicz et al. (unpubl.) used measurements of standing stocks and literature-based rates to estimate a total SoG crustacean zooplankton community production rate (annual average) of $213 \mathrm{mg} \mathrm{C} \mathrm{m}^{-2}$ $\mathrm{d}^{-1}$. By comparison, our average, minimum and maximum depth-integrated chitobiase-based estimates were $272.50,74.80$ and $498.78 \mathrm{mg} \mathrm{C} \mathrm{m}^{-2} \mathrm{~d}^{-1}$. Harrison et al. (1983) estimated a mean daily primary production rate of 0.7-0.9 g C m $\mathrm{C}^{-1}$. More recently, R. Pawlowicz et al. (unpubl.) estimated a greater average primary production rate in the SoG as $1.2 \pm 0.2 \mathrm{~g} \mathrm{C}$ $\mathrm{m}^{-2} \mathrm{~d}^{-1}$ using data collected at our sampling station during a period encompassing the present study (2002-2005). Given our mean BP and the higher mean PP estimate we calculate an average transfer efficiency (TE) of 0.23 . This TE is greater than what is conventionally assumed for phytoplankton-zooplankton $(<0.1)$ as well as that estimated using our literaturebased estimate of BP (0.045). Further, our estimates of TE are also elevated because the CBA-based estimates of BP are averaged over the most productive periods of the year (spring and early summer) and compared to an annual primary production estimate.

On average, the CBA-based estimates of P:B were $\sim 2$ times greater than in situ predictions using the literature-based growth models (Hirst \& Bunker 2003, Hirst et al. 2003). However, we note that the literature-based estimates are assembled from in situ rates and cannot estimate food saturated rates. Moreover, most of the CBA-based point estimates of daily P:B are in good agreement with the literature-based estimates. The major discrepancy is attributed to 3 dates: 11 August 2004, 7 April 2005 and 16 May 2005. The CBA-based $\mathrm{P}: \mathrm{B}$ estimate on each of these dates is $>0.3$ relative to an average in situ estimate of 0.09 . In each case, the biomass of the developing fraction of the copepod community was high, suggesting that production and biomass of animals not captured by our $236 \mu \mathrm{m}$ SCOR net may not have been accounted for. In all 3 cases, the biomass of the copepod communities were dominated by early stage Calanus pacificus and those smaller species (i.e. Acartia sp. Pseudocalanus spp., Paracalanus sp. and Oithona spp.) whose naupliar and early copepodites stages were not sampled. The CBA-based estimates, however, are assumed to include production of smaller animals moulting and growing at greater rates than the larger animals collected in our net, potentially accounting for the greater biomass turnover rate.

\section{Interannual variation of zooplankton productivity}

Biomass development started $\sim 2$ to 3 wk earlier in 2005 than 2004. BP in late February 2005 was higher than in 2004, reflecting an earlier development of Metridia pacifica and Calanus pacificus. However, the most striking difference between years was the virtual absence of Neocalanus plumchrus in 2005. Late-stage nauplii and first-stage copepodites arrived in the surface waters during February to mid-March in 2004. Coupled with rapid growth, this continuous recruit- 
ment accounted for $~ 70 \%$ of copepod and $>60 \%$ of the crustacean zooplankton community biomass by early April 2004. BP rates during this period rose steadily until the end of April.

In contrast, BP in 2005 was relatively high during the development of the spring phytoplankton bloom (midto late February) but declined rapidly to $<2 \mathrm{mg} \mathrm{C} \mathrm{m}^{-3}$ $\mathrm{d}^{-1}$. This coincided with a high proportion of adults relative to total copepod biomass $(70 \%$ on 8 March 2005 versus $35 \%$ on 29 March 2004). By the end of March 2005, crustacean zooplankton biomass had declined by $59 \%$ with virtually no change in the mean Neocalanus plumchrus developmental stage ( CII). By 7 April 2005, BP had increased to $9.91 \mathrm{mg} \mathrm{C} \mathrm{m}^{-3} \mathrm{~d}^{-1}$. However, most of this production is attributed to groups other than N. plumchrus, as the surface recruitment period had concluded and the $N$. plumchrus biomass of in the surface and deeper waters was very low (El-Sabaawi et al. 2009a). During the late-spring of 2004, the biomass of euphausiids captured in our net tows was $\sim 42 \%$ greater than in mid-May 2005. Recognizing that our SCOR net tows underestimate euphausiid biomass, it is still worth noting that this implies a considerable decline in euphausiid biomass between 2004 and 2005.

Potentially important differences between 2004 and 2005 include: (1) the timing and intensity of surface stratification; (2) the timing of the spring phytoplankton blooms; (3) the rate of nutrient depletion; and (4) the relative dominance of diatom biomass (see Figs. 1 $\& 2$ ). We hypothesize that in 2005 , intense stratification promoted nutrient stress in a diatom-dominated phytoplankton community that adversely impacted the productivity of consumers. The negative influence of nutrient-stressed diatoms on zooplankton development has been reported from laboratory studies. For example, Klein Breteler et al. (2005) reared copepods on diatoms that were variously nutrient-limited and found a significant negative influence on development that was correlated with variability of the fatty acid composition of the diatom diet. Indeed, significant changes in the fatty acid profiles of individual Neocalanus plumchrus indicate a shift in diet quality that coincided with the period (March 2005) of relatively low BP rates (El-Sabaawi et al. 2009a).

Also of interest is the marked elevation of BP observed on 7 April 2005. By this sampling date, the degree of stratification had declined and surface nitrate, phosphate and silicate concentrations had increased from near zero to 22.7, 2.0 and $37.5 \mu \mathrm{M}$, respectively. Although diatoms still represented $>90 \%$ of the phytoplankton biomass, the beginning of April also marked an increase in crustacean zooplankton biomass. Phytoplankton biomass in the $>2 \mu \mathrm{m}$ size fraction during March and early April was never less than $6.6 \mathrm{\mu g} \mathrm{l}^{-1}$. As diatoms comprised $>90 \%$ of nano- and microplankton biomass, food limitation can only be invoked provided that copepods were entirely avoiding diatoms. In the absence of direct estimates of copepod ingestion rates and food quality (i.e. elemental composition and/or fatty acid profiles), we cannot definitively attribute variation in BP and the collapse of Neocalanus plumchrus to the impact of nutrient stress on a diatom-based diet. However, the $\delta^{15} \mathrm{~N}$ signatures of $N$. plumchrus during 2005 classify this copepod as almost entirely herbivorous (El-Sabaawi et al. 2009b). It is also possible that conditions in 2005 promoted other physiological responses of diatoms to nutrient stress (e.g. toxicity; Ribalet et al. 2007) that negatively influenced zooplankton productivity.

Several studies have deemed 2005 an anomalous year in the northeast Pacific, with a late ( 50 d) initiation of spring upwelling and anomalously low levels of primary production (Kosro et al. 2006, Kudela et al. 2006). A historically low hatching success of the planktivorous Cassin's auklet Ptychoramphus aleuticu on Triangle Island, British Columbia (Sydeman et al. 2006), represents a notable higher trophic level response. Furthermore, zooplankton biomass anomalies extending from northern California to southern Vancouver Island (Mackas et al. 2006) suggest that low mesozooplankton production in the SoG may also have been related to larger scale atmospheric and oceanographic anomalies.

\section{CONCLUSIONS}

The activity of chitobiase produced by individuals was sufficiently similar across 3 morphologically different groups (copepods, decapod larvae and mysids) to justify description with a single relationship. Application of this size-based relationship to the contents of our net casts demonstrated that the native activity of chitobiase in the water column covaried with netbased estimates of biomass.

In general, chitobiase turnover rates varied with temperature-dependent expectations. Further validation of this method should include a careful consideration of the relationship between individual CBA and the increment of growth. This is especially important for groups (e.g. euphausiids versus copepods) that do not share the same relationship between body size and growth increment. The primary advantages of the chitobiase method are that: (1) community-level estimates of production may be estimated at sea using short-term $(\sim 12 \mathrm{~h})$ incubations of seawater; and (2) direct estimates are not dependent on conventional estimates of biomass and growth rate. In summary, chitobiasebased estimates of biomass production varied with expectations of the seasonal cycle of zooplankton bio- 
mass in the SoG. Given the practical difficulties with conventional methodology and the global paucity of secondary production estimates, further development and application of this method is warranted.

Acknowledgements. We thank the captains and crews of the MSV 'John Strickland' and the CCGS 'Siyay'. W. Duguid is gratefully acknowledged for helping collect mysids and providing animals from his larval crab cultures. We also thank 3 anonymous reviewers for helpful comments and suggestions that improved this manuscript. This study is a contribution from the Strait of Georgia Monitoring Study (STRATOGEM), funded by the Natural Sciences and Engineering Research Council of Canada.

\section{LITERATURE CITED}

Bird DF, Prairie YT (1985) Practical guidelines for the use of length-weight regression equations. J Plankton Res 7: 955-960

Campbell RG, Runge JA, Durbin EG (2001) Evidence for food limitation of Calanus finmarchicus production rates on the southern flanks of Georges Bank during April 1997. DeepSea Res II 48:531-549

Crain JA, Miller CB (2001) Effects of starvation on intermolt development in Calanus finmarchicus copepodites: a comparison between theoretical models and field studies. Deep Sea Res II 48:551-566

Duguid WDP, Page LR (in press) Larval and early post-larval morphology, growth, and behaviour of laboratory-reared Lopholithoides foraminatus (brown box crab). J Mar Biol Assoc UK

El-Sabaawi RW, Dower JF, Kainz M, Mazumder A (2009a) Interannual variability in fatty acid composition of the copepod Neocalanus plumchrus in the Strait of Georgia, British Columbia. Mar Ecol Prog Ser 382:151-161

El-Sabaawi RW, Dower JF, Kainz M, Mazumder A (2009b) Characterizing dietary variability and trophic positions of coastal calanoid copepods: insight from stable isotopes and fatty acids. Mar Biol 156:225-237

Harrison PJ, Fulton JD, Taylor FJR, Parsons TR (1983) Review of the biological oceanography of the Strait of Georgia pelagic environment. Can J Fish Aquat Sci 40: 1064-1094

Hirst AG, Bunker AJ (2003) Growth of marine planktonic copepods: global rates and patterns in relation to chlorophyll $a$, temperature, and body weight. Limnol Oceanogr 48:1988-2010

Hirst AG, Roff JC, Lampitt RS (2003) A synthesis of growth rates in marine epipelagic invertebrate zooplankton. Adv Mar Biol 44:1-142

Hollibaugh JT, Azam F (1983) Microbial degradation of dissolved proteins in seawater. Limnol Oceanogr 28: 1104-1116

Huntley ME, Lopez MDG (1992) Temperature-dependent production of marine copepods: a global synthesis. Am Nat 140:201-242

Kiørboe T, Sabatini M (1995) Scaling of fecundity, growth and development in marine planktonic copepods. Mar Ecol Prog Ser 120:285-298

Klein Breteler WCM, Schogt N, Rampen S (2005) Effect of diatom nutrition limitation on copepod development: role of essential lipids. Mar Ecol Prog Ser 291:125-133

Knotz S, Boersma M, Saborowski R (2006) Microassays for a set of enzymes in individual small marine copepods. Comp Biochem Physiol A 145:406-411

Kosro PM, Peterson WT, Hickey BM, Shearman RK, Pierce SD (2006) Physical versus biological spring transition: 2005. Geophys Res Lett 33:L22S03

- Kudela RM, Cochlan WP, Peterson TD, Trick CG (2006) Impacts on phytoplankton biomass and productivity in the Pacific Northwest during the warm ocean conditions of 2005. Geophys Res Lett 33:L22S06

Mackas DL, Peterson WT, Ohman MD, Lavaniegos BE (2006) Zooplankton anomalies in the California Current system before and during the warm ocean conditions of 2005 . Geophys Res Lett 33:L22S07

McIlvaine TC (1921) A buffer solution for colorimetric comparison. J Biol Chem 49:183-186

> Oosterhuis SS, Baars MA, Klein Breteler WCM (2000) Release of the enzyme chitobiase by the copepod Temora longicornis: characteristics and potential tool for estimating crustacean biomass production in the sea. Mar Ecol Prog Ser 196:195-206

Paffenhöfer GA, Harris RP (1976) Feeding, growth and reproduction of the marine planktonic copepod Pseudocalanus elongatus. J Mar Biol Assoc UK 56:327-344

Parsons TR, LeBrasseur RJ, Fulton JD, Kennedy OD (1969) Production studies in the Strait of Georgia. Part II. Secondary production under the Fraser River plume. February to May, 1967. J Exp Mar Biol Ecol 3:39-50

Pawlowicz R, Riche O, Halverson M (2007) The circulation and residence time of the Strait of Georgia using a simple mixing-box approach. Atmos-Ocean 45:173-193

> Peterson WT, Gomez-Gutierrez J, Morgan CA (2002) Crossshelf variation in calanoid copepod production during summer 1996 off the Oregon coast, USA. Mar Biol 141: 353-365

Ribalet F, Wichard T, Pohnert G, Ianora A, Miralto A, Casott R (2007) Age and nutrient limitation enhance polyunsaturated aldehyde production in marine diatoms. Phytochemistry 68:2059-2067

Roff JC, Kroetsch JT, Clarke AJ (1994) A radiochemical method for secondary production in planktonic crustacea based on the rate of chitin synthesis. J Plankton Res 16: 961-976

Runge JA, Roff JC (2000) The measurement of growth and reproductive rates. In: Harris $\mathrm{RP}$, Weibe $\mathrm{PH}$, Lenz J, Skjoldal HR, Huntley M (eds) ICES zooplankton methodology manual, Chap. 9. Academic Press, San Diego, CA, p 401-454

Sastri AR, Dower JF (2006) Field validation of an instantaneous estimate of in situ development and growth for marine copepod communities. Can J Fish Aquat Sci 63: 2639-2647

Sastri AR, Roff JC (2000) Rate of chitobiase degradation as a measure of development rate in planktonic Crustacea. Can J Fish Aquat Sci 57:1965-1968

Steeman-Neilsen E (1952) The use of radioactive carbon $\left({ }^{14} \mathrm{C}\right)$ for measuring organic production in the sea. J Cons Int Explor Mer 144:92-95

Stehle M, Dos Santos A, Querioga H (2007) Comparison of zooplankton sampling performance of Longhurst-Hardy plankton recorder and bongo nets. J Plankton Res 29: 169-177

Sydeman WJ, Bradley RW, Warzybok P, Abraham CL and others (2006) Planktivorous auklet Ptychoramphus aleuticus responses to ocean climate, 2005: unusual atmospheric blocking? Geophys Res Lett 33:L22S09

Vrba J, Machacek J (1994) Release of dissolved extracellular $\beta-\mathrm{N}$ acetylglucosaminidase during crustacean moulting. Limnol Oceanogr 39:712-716 